\title{
Donor eller donator?
}

\author{
Det vakte oppsikt da forfatteren Tor Bomann-Larsen i oktober 2004 antydet at kong Olav ikke \\ var kong Haakons sønn. Kunne det ha vært den engelske livlege sir Francis Laking (1847-1914) \\ som hadde vært behjelpelig med å sikre kongedømmets eksistens? Var dr. Laking en donator \\ eller en donor?
}

Svaret er at han sannsynligvis ikke var noen av delene (1), men språklig sett er det en betydningsforskjell som er verdt å merke seg (2). Til grunn for begge formene ligger det latinske verbet donare, som betyr å gi.

\section{Donere}

Donere har lenge vært brukt om det å gi bort noe av stor verdi eller betydning for mottakeren. Det kan f.eks. være en større pengesum eller fast eiendom som blir overlatt til allmennyttige formål. Ordet blir altså brukt med en spesiell betydningsnyanse og på et spesielt bruksområde som gjør det nyttig ved siden av mer hverdagslige ord som «gi» og andre synonymer. Mottakere av en donasjon er ofte samfunnet eller veldedige organisasjoner (3). Gavemottakeren kan kalles donatar, men dette ordet er lite brukt på norsk.

I 1950-årene fikk donere et nytt bruksområde. Siden da har man kunnet gi bort noe også i medisinsk øyemed, som blod, sæd, egg, vev eller organer til transplantasjon. Men språkbruken er ikke helt konsekvent. Mens det er vanlig å si at man donerer sæd eller egg, er det fortsatt vanlig å si at man gir blod.

\section{Donator, donor, donasjon}

En person som donerer noe kan enten være en donator eller en donor. Donator betegner en person som gir noe til høyverdige formål, mens donor er en som gir noe fra egen kropp. Donor er et forholdsvis nytt ord, det ble notert i bruk i norsk i 1952

(3-5). Ut fra ordlagingsmønsteret $i$ latin er donor en uheldig språklig konstruksjon (6), men det er tatt inn i norsk via engelsk (5). Interessant nok dekker donor på engelsk begge betydningene - her er altså norsk mer nyanserikt enn engelsk $(2,7)$.

Tradisjonelt kalles det som doneres for en donasjon, men det gjelder ikke i medisinsk sammenheng. Det er kun donator som skjenker en donasjon.

Donor brukes også på dansk, bl.a. i en rekke sammensatte ord: donorbarn, donorblod, donorhjerte, donorkort, donorkorps $(8-10)$. Det ble registrert i bruk før den annen verdenskrig særlig i betydningen bloddonor, senere er bruken utvidet $\mathrm{i}$ takt

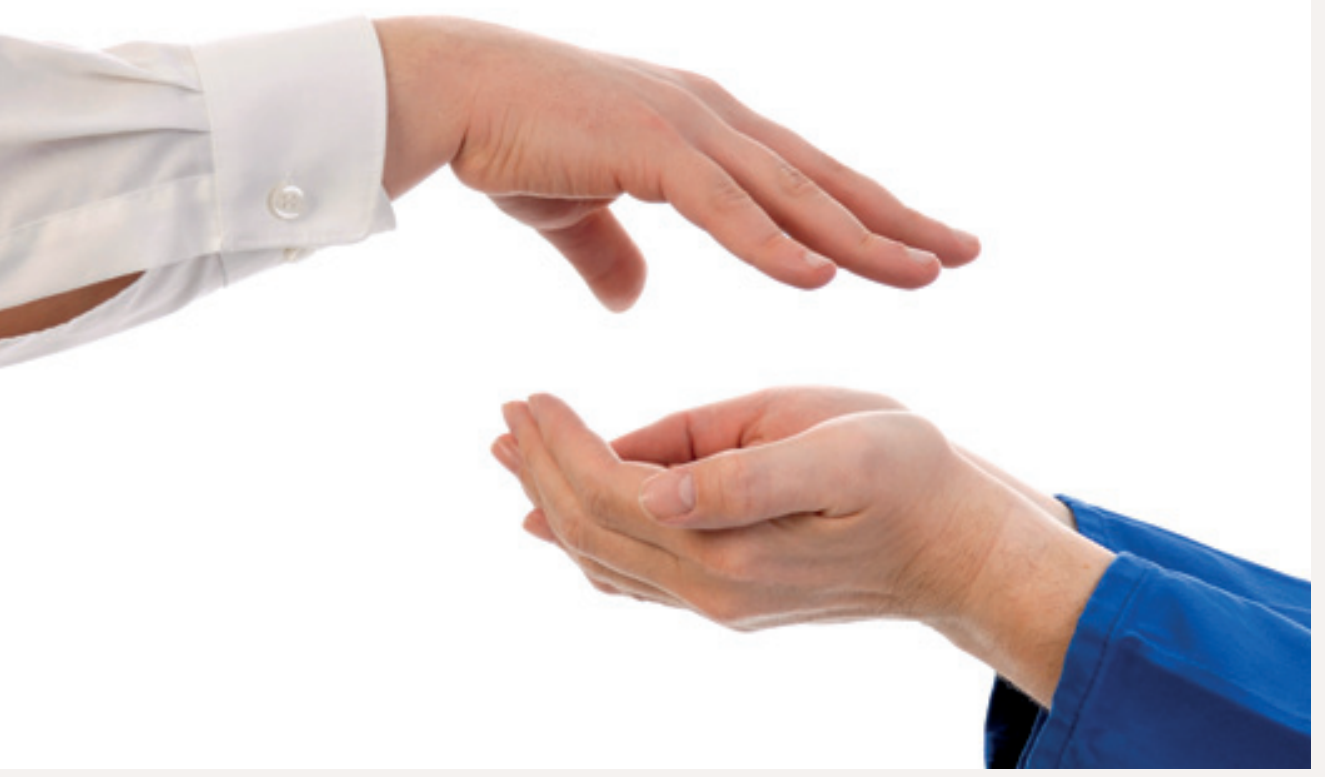

med den medisinske utviklingen (10). Donor finnes imidlertid ikke på svensk, der brukes donator i begge betydninger $(11,12)$.

\section{Uttale}

Personbetegnelsen donor er dannet på samme måte som rektor, lektor, professor osv. I entall leses donor med trykk på første stavelse. Vanligvis skal trykket flyttes i flertall av slike ord, altså [donor] (trykk på den første o-en) - [donorer] (trykk på den siste o-en) (13). Men det spørs om denne regelen om trykkforskyvning lar seg opprettholde for et nytt ord som donor (3).

Enkelte ordbøker angir at donor uttales med å-lyd i annen stavelse: [donår] $(4,14)$ - og at det også gjelder i flertall: [donårer] (15). Men dette er ikke i samsvar med vanlig uttalepraksis (2). Varianten [donor] er den gjengse, på samme måte som i [rektor], [lektor] osv.

\section{Erlend Hem}

erlend.hem@medisin.uio.no

Tidsskriftet

\footnotetext{
Litteratur

1. Bomann-Larsen T. Folket. Bd 2 i serien: Haakon \& Maud. Oslo: Cappelen, 2004

2. Vinje F-E. Ut med språket. Oslo: Schibsted, 2005: 113-4.

3. Lundeby E. Donasjon. I: Språkrøret NRK radio 19.5.1990.

4. Norsk riksmålsordbok. 2. utg. Bd. 5. Oslo: Kunnskapsforlaget, 1995: 595.

5. Leira V, red. Nyord i norsk 1945-1975. Bergen: Universitetsforlaget, 1982: 97

6. Flo $\AA$, Ødegaard R. Legelatin i et nordisk perspektiv. Tidsskr Nor Lægeforen 2000; 120: 2053.

7. Donor. I: Simpson JA, Weiner ES, red. The Oxford English Dictionary. 2. utg. Bd. 4: creel-duzepere. Oxford: Clarendon Press, 1989: 954. http:// dictionary.oed.com/cgi/entry/50068628 (26.4.2010).

8. Bergenholtz H, Pedersen J, Vrang V et al, red. Danskordbogen. Århus: Systime, 1999: 238.

9. Jarvad P. Nye ord: ordbog over nye ord i dansk 1955-1998. København: Gyldendal, 1999: 216.

10. Det Danske Sprog- og Litteraturselskab. Ordbog over det danske sprog, supplement. Bd. 2: bidozer. København: Gyldendal, 2005: 1414.

11. Svenska akademiens ordlista över svenska språket. 13. utg. Stockholm: Norstedts Akademiska Förlag, 2006: 157.

12. Svensk ordbok. Utarbetad vid Språkdata, Göteborgs universitet. 3. utg. Stockholm: Nordstedts ordbok, 1999: 221.

13. Vinje F-E. Bloggarkiv. Donator og donor. 26.5.2009 www.finnerikvinje.no (22.2.2010).

14. Berulfsen B. Norsk uttaleordbok. Oslo: Aschehoug, 1969: 71 .

15. Guttu T, red. Aschehoug og Gyldendals store norske ordbok: riksmål og moderat bokmål. 2. utg. Oslo: Kunnskapsforlaget, 2005; 5: 142.
} 